\title{
The Impact of 21st Century Competencies on Future Job Seekers' Diversity Readiness: A Developmental Perspective
}

\author{
Chee Yen, LOH, \\ Ph.D. Student, LJMU, UK \\ Principal Lecturer \\ TMC Academy, Singapore \\ Dr. Teck Choon TEO, DBA \\ Associate Dean \\ RVi Institute, Mandalay, Myanmar \\ Fellow, Chartered College of Teaching, UK
}

\begin{abstract}
There has been much discussion among international institutions such as OECD, Partnership21 and even Singapore Ministry of Education for the call to better develop students equipping them for the future workplace. While there may be slight variation of 21 st century competencies skills, however, the foci will largely be in the cognitive, intrapersonal and interpersonal domains. The purpose of this article is to propose possible approaches to facilitate 21st century competencies in the classroom; especially with the emphasis on how education systems are addressing 21st century skills and leadership perspective. First, the themes of 21st century competency are discussed. Then based on the literature, several strategies and ideas of promoting 21 st century competencies are reviewed. Next, a possible model is proposed, including teachers' and learners' perspective and supportive educational leadership. With each component, several propositions are also provided. Finally, the implication of unifying theme is described, where we teach learners to teach themselves.
\end{abstract}

Key words: 21 st century competencies, future learners, learning approaches, technologies,

\section{Introduction}

Institutions of higher learning across countries are responding to teaching pedagogies and technological pressures to be more responsive to students' needs and more concerned about how well students are prepared to assume future societal roles. Faculty are already feeling the pressure to lecture less, to make learning environments more interactive, possibly integrating technology where appropriate into the learning experience, and to use collaborative learning strategies when suitable. Therefore, there is a need for a greater understanding of the dynamics between the personal and contextual factors responsible for students' learning in the classroom. Like it or not, teacher s serve as the metronome in the classroom. The tempo and behaviour established by them set the patterns and establish the models for students' learning attitude as individuals and as a group. Consequently, there is a need to identify the role of lecturer leadership behaviours for students' learning. Specifically, in the education sector, our knowledge transforming students into future ready and the creative process remains limited. The importance of the identification of factors that amplify or stifle students' creative behaviours is fostering the structure of classroom environments which is conducive to learning new skills that will enable students to thrive in their future employment.

The importance of pedagogical change was a key thrust from the "Teach Less, Learn More" (TLLM) movement in Singapore became hugely popular in 2005 and became one of the key pillar in enhancing the quality of education through reducing syllabuses so that students have more space to learn and explore (Koh, 2013; MOE, 2005). Interestingly the TLLM concept was influenced by $21 \mathrm{CC}$ education which entails innovative pedagogies such as inquiry-based learning that necessitates more curriculum time (Teo, Deng, Lee, \& Lim-Ratnam, 2013).

Lee and Hung (2016) documented that school leadership was pivotal in the launch and implementation of the pedagogical innovation. Their paper reported the role of the school leader in providing (1) the socio-technological resources for the teachers to experiment in the classroom, (2) learning support and professional development that shifted the pedagogy, curriculum, and assessment, (3) a structure of teacher learning communities to sustain innovation efforts, and (4) feedback mechanisms and time for teachers to develop and refine the curriculum. 
By comparing authentic learning which emphasise is on the application of thinking skills, connecting knowledge across subject disciplines and experiential learning based on real-life experiential learning to develop their character and values, cultivate positive attitudes, self-expression, and strengthen their people skills, the hypothesis for the 21st century competencies learning can be integrated vis knowledge and attitude component.

Furthermore, Acedo and Hughes (2014) similarly argued the importance of learning STEM (science, technology, engineering, and mathematics), concept-focused learning, information literacy are needed for authentic learning and the portion of academic honesty, health and mindfulness, service learning is crucial to prepare students for the complexity of the 21 st century.

Indeed education is both an enriching and integrating force. Learners are inspired as they acquire skills and knowledge to enriched lives and the capacity to contribute to society and fulfilling their dreams. It is also an integrating force, as learners improve their lives through education, thus narrowing the inequality gaps. However, today's rapid technological advancements impose a short validity on the skills and knowledge one acquired in schools and higher education, and moreover, globalisation has widened social inequality. We will need to ensure that education will continue to enrich lives and prepare today's learners for the future. This is the central question every educator in the world is asking - how to prepare young learners for the future?

Returning back to the theme TLLM, this was framed from a global perspective which arguably is relevant and vital to facilitate learners meeting the challenges of an uncertain, fluid future, educators now require the impetus to usher the a new phase of change - one that is framed around the students' perspective. The basic intent is to shift the focus from "quantity" to "quality" in education. More quality in the context of classroom interaction vis opportunities for expression, the learning of life-long skills and the building of character via innovative and effective teaching approaches and strategies. Less quantity in the context of rote-learning, repetitive tests, and following prescribed answers and set formulae. In order to engage learners, educators will need to embrace the "why," "what," and "how" of teaching in order to teach less for content coverage and more for developing learners holistically. In the premise of TLLM learners are actively involved in the process of learning more to be prepared for life and less for the sake of assessments/exams. Evidently, there are two indispensable facets of TLLM. First, there is a notion of engaged learners and second, there is an appeal for educators and managers to ensure value of education is delivered effectively and efficiently to learners in view of the need to prepare students for the twenty-first century.

\section{Literature review}

\section{Understanding 21 st century competency and learning}

Various international bodies such as the Organisation for Economic and Co-operation Development (OECD), Partnership for 21st century skills (2008), the European Commission and the National Research Council and APEC have been urging education regulators and institutions to better prepare students for the workplace of tomorrow. A fundamental and crucial question about the future, then, is whether formal and informal learning approaches will evolve to address the changing needs of learners who wish to fulfill the workplace expectations of the future. If the answer is yes, then educators must move quickly to address key considerations:

(a) What are the most important skills needed to succeed in the workforce of the future?

(b) Will learning and teaching pedagogies of 21 st century competencies be different - basic needs and enables learners to be prepared to learn

(c) How can the development of 21 st century competencies become an integrated part of the education system?

According to PS21 framework, 21st century competency describes the skills, knowledge and expertise students should master to succeed in work and life in the 21 century (Kay, 2008). It emphasises on the 4Cs - Critical thinking and problem solving, Communication, Collaboration, Creativity and innovation. The 21 st century competencies foundation classify 21st century competencies as associated with cognitive growth vis-à-vis growth of cognitive, interpersonal and intrapersonal domains succeed. Furthermore, Cedefop (2016) contended that 21 st century competencies as associated with "deeper learning", "global competencies", "next generation learning" and "higher order thinking". The term skills and competency are often used interchangeably. In the same vein, Cedefop (2016) described "skills" and "competencies" as somewhat different. The ability to execute and solve problems is a skill and apply knowledge is a competency. Therefore, competency encompasses not only cognitive skills set but also includes interpersonal attributes. Singapore MOE too has identified a set of competencies which schools in Singapore are required to deliver holistic education to better prepare students in the future workplace (MOE, 2016). 


\section{1st century framework common theme}

It is fascinating to note that in the past century, the overall K-12 learning is about institutions and the net outcome has been a society with very little capacity for mastering the process of learning itself, and generations of students that went to school to "get a job" rather than the pursuit of innovation, entrepreneurship and competency to thrive in the society. In a sandbox learning environment, learners are able to interact seamlessly with content without the intrusion of monitoring, assessment, or having to decipher what teacher's thoughts or messages. A positive outcome of the sandbox learning is the willingness to experiment, to understand, to follow curiosity, and to hold one's self accountable to personal standards for achievement. It is the provision of a safe environment for educators and managers to try-out innovative learning solutions.

Education has changed with the advent of advanced technology and artificial intelligence (AI) and will continue to change. The incorporation of mobile devices and other technology forces students and educators to became technologically literate if they are to use the system properly. These skills are needed to compete in the constantly changing work environment. Incorporating these skills into the traditional curriculum only benefits those who aspire to do more with their education. Learners invariably gain a competitive advantage in the job market through acquired literacy skills in information, media and technology. They increase their skills by becoming capable of adapting to rapidly changing work environments. The innovative nature of technology and digital learning, as it continues to change and expand, will require educators and managers to adapt and change quickly the way they approach teaching and learning. Clearly, the future of education will see a major change with the expansion of technology. However, that change depends on willingness of educators and managers to adopt advanced technology and artificial intelligence into educational institutions and the manner in which they administer it.

In another vein, the collective leadership for systemic transformation and the notion of life-long learning is increasingly touted as an antidote, as it underpins one's value, attitude and skill that today's learners need to possess. Fundamentally, it ensures that education remains an inspiring force in society, indeed, a principal consideration for educational institutions for learners to be future ready.

Given this backdrop, it is crucial to recalibrate the education system and assess if fine-tuning to the system is required. Furthermore, by building an innovation ecosystem in education that keeps on rejuvenating itself would then enable learners to succeed in their given profession later in life. It is by providing further space, freedom and support, i.e. "safe environment" for schools, educators and managers to conduct experiments will be important to jointly tackle this complex challenge.

The Education Endowment Foundation (EEF 2018) on the other hand, contends that the impact of collaborative learning is consistently positive, although it does highlight that this impact can be affected by group size and poor planning. They argue that the main learning benefits are as a result of structured approaches and well-designed tasks and continue to say that approaches which encourage talk and interaction between learners tend to have best gains. Johnson, Johnson, and Smith (2014) conducted 168 studies comparing cooperative learning to competitive learning (students working alone) among university students, and found that cooperative learning produced greater academic achievement. Discussing their findings, Brame and Biel (2015) advocate that cooperative learning is characterised by positive interdependence, where students perceive that better performance by individuals produces better performance by the entire group and argue that collaborative working is an adaptable approach, working for small or large groups.

Over the decade, international organisations have varying classifications on the type of skills 21 st century competencies may consist. Table 1 provide a summary of three such organisations. 
Table 1: Overview of international 21CC education frameworks

\begin{tabular}{|c|c|c|}
\hline $\begin{array}{l}\text { Partnership for 21st Century } \\
\text { Skills (P21) }\end{array}$ & $\begin{array}{l}\text { Assessment and Teaching of 21st } \\
\text { Century Skills (ATC21S) }\end{array}$ & $\begin{array}{l}\text { OECD Definition and Selection } \\
\text { of Competencies (DeSeCo) }\end{array}$ \\
\hline $\begin{array}{l}\text { Learning and Innovation Skills } \\
\text { Creativity and innovation } \\
\text { Critical thinking and problem- } \\
\text { solving } \\
\text { Information, Media and } \\
\text { Technology skills } \\
\text { Information Literacy } \\
\text { Media Literacy } \\
\text { ICT Literacy } \\
\text { Learning and Innovation Skills } \\
\text { Communication } \\
\text { Collaboration } \\
\text { Life and Career Skills } \\
\text { Flexibility, adaptability } \\
\text { Initiative, self-direction } \\
\text { Social, cross-cultural skills } \\
\text { Productivity, accountability } \\
\text { Leadership, responsibility }\end{array}$ & $\begin{array}{l}\text { Ways of Thinking } \\
\text { Creativity and innovation } \\
\text { Critical thinking, problem-solving, } \\
\text { decision-making } \\
\text { Learning to learn, meta-cognition } \\
\text { Tools for Working } \\
\text { Information Literacy } \\
\text { ICT Literacy }\end{array}$ & $\begin{array}{l}\text { Interacting in Heterogeneous } \\
\text { Groups } \\
\text { Relate well with others } \\
\text { Cooperate, work in teams } \\
\text { Manage and resolve conflicts } \\
\text { Acting Autonomously } \\
\text { Form and conduct life plans and } \\
\text { personal projects } \\
\text { Defend and assert rights, interests, } \\
\text { limits and needs }\end{array}$ \\
\hline
\end{tabular}

Sources: Lee and Tan (in press); Partnership for 21st Century Skills (2012); Binkley et al. (2012); OECD (2005) cited in Tan, Choo, Kang \& Liem (2017).

From the above, 21st century competencies otherwise known as 21CC propose that cognitive and interpersonal skills that are intertwined. Cognitive thinking skills are higher order thinking skills such as critical-thinking skills analytical and problem-solving skills. While in the past possessing cognitive skills was needed to be successful, but in today's competitive world, coupled with technological and social advances, learners today are required to possess mastery of digital, information technology and media literacy as essential skills in the cyberspace and global community.

Intuitively students derive much delight in learning, when they move away from memorisation, rote learning, drilling and taking formal examinations. It is not to say that these are undesirable traits in learning. Indeed it is the foundational approach in learning and strategy for advanced concepts and learning, and can inculcate discipline and resilience, ensuring students to have confidence in tackling complex problems and finding solutions. But there needs to be a balance between rigour and delight in learning. By tilting to the latter, learners can become resilient and be future ready for employment in their given fields.

Weston and Clay (2018) refer to a work culture that supports learning as being one where teachers "feel that learning is exciting and engaging" and "feel a sense of belonging, that they are trusted, nurtured and given the time and space to grow and develop" (p. 65). Wiliam (2016) also interjected that time is needed for professional learning. But as time is always in short supply, Wiliam (2016) correctly emphasised that "if improvement is to occur, most of it will be generated by the teacher's own efforts to improve" (p. 239). Teachers themselves need to be motivated to improve, their school culture thus has to be not just a learning-based culture (for teachers), but also a culture that nurtures those teachers' motivation. 


\section{Why the need for 21 st century competencies?}

Information technology has become an inseparable part of our life and social fabric. A new network generation of people that cannot imagine life without new technological devices is growing. However, despite of this, modern education does not sufficiently influence the development of human capital in the conditions of digital environment.

A number of organisations have documented the efforts of educators to deliver 21st century competencies in their classrooms (OECD, 2016; 21CC, 2013; Asia Society, 2016; Singapore MOE, 2010). Educational researchers have justified that 21st century competencies can be both learned and taught through proper training programmes with educators' conscious contributions and developing suitable pedagogies with safe learning environment (Davis, 2006; Saracho, 2002). In line with this notion, other writers suggest creative thinking should be blended into the curricula, and with a more pluralistic approach can assist students to increase their quantity and quality of ideas (Lau, $\mathrm{Ng}, \&$ Lee, 2009; Puccio \& Keller-Mathers, 2007).

OECD (2016) posited that there is a gap between organisations having access to internet and employees with the information technology (IT) skills. For instance, $95 \%$ of employees in large organisations and $85 \%$ in medium-sized enterprises have readily access to and use the internet as part of their jobs. Yet, just $56 \%$ of the workforce does not have the skills to complete tasks in a technology-rich environment. On the other hand, 21CC maintained that 21st century competencies are needed to cope with the demands of the 21 st century challenges. Fundamental changes occurring in today's economies, particularly in developed economies like in United States and Singapore. In the case of Singapore, the share of manufacturing to the nation's gross domestic product (GDP) has fallen from a high $70 \%$ to $30 \%$ from the sixties till 2015. Instead of manufacturing, service sector such as banking and finance, information technology and trade and commence dominates the economy. Moving forward, this would imply that the skills required will also move in tandem vis from hard to soft skills (21st century competencies foundation document for discussion, 2016). In Singapore, the segment of Professionals, Managers, Executives (PME) has risen from $44 \%$ to over $62.2 \%$ of total employment in 2011. In contrast, for production, operators and cleaners percentage has fallen from $29 \%$ to $23.1 \%$ over the corresponding period. This decline is similarly reflected in developed economies like the United States where 80\% of all jobs are in the service sector (Carnevale, 2013).

Currently, businesses operating in the on-demand economy are an extension of conventional services repacked into new modes of delivery and accommodating to a wide range of users (Chesbrough, 2013; Juggernaut, 2016). The buzz-word, On-Demand refers to the economic opportunity and activities developed by technology-driven companies to fulfil consumer demand via the immediate supply of goods and services (Patel, 2016). The supply side of on-demand technologies is programmed via an intuitive and efficient digital layer existing on top of infrastructure networks. Such methods are not only efficient but revolutionary, as they provide fast and effective solutions to everyday problems. Start-ups using the on-demand business model have made fortunes overnight using on-demand technology.

Aside from the changes in the economy, the nature of business is also evolving. The concept of lean management is nowadays very prevalent and this can be traceable to advanced technology and artificial intelligence. It can be seen both in its frequent implementation in various organisations and in the scientific papers focusing on its different aspects. The significance of the lean concept, both for theory and practice of management, and its viability, demonstrated in continuous development of the concept itself and its applications. This has significant implications for organisations and their expectations of employees' contribution of output. For instance, employees at different levels need to exercise some degree of decision-making where they are empowered by management. In turn Carnevale (2013) believe cross-functional teams have taken over the office realms necessitating employees to cooperate and collaborate not only within the organisation but also externally in a project team.

Schools nowadays are required to prepare students for a changing world. In this climate of rapid change, teachers are urged to become knowledge workers (Schleicher, 2015) and to facilitate vast amounts of information and knowledge in assisting their students become better learners. There is some evidence from work in the international arena (OECD, 2013) that some traditional models of organising learning in schools may have difficulties meeting the needs of learners. However, all schools in Singapore, both the curriculum and pedagogical approaches to classroom learning are innovative and very relevant to learner's needs.

In information-rich societies like in the United States, UK and Singapore, knowledge is a critically important commodity but, as Celik (2014) maintains, individual learning is insufficient to sustain organisations. It is now common for organisations to implement 'organisational learning strategies' aimed at improving an organisation's performance. Most successful organisations describe themselves as learning organisations (Vemić, 2007), and organisations that consciously promote structures and strategies concerning organisational learning are very much learning organisations. 
All sustainable organisations and indeed similar for schools, are those where learning is crucial to everything they do. Successful schools replace 'schooling' with learning. They fully embrace that learning is multifaceted involving not only student learning but also that of all teachers and other stakeholders. They build cultures and systems that support the notion of "learning to learn". O'Neil (1995) contends that since both education and business have to face rapid changes in the world, both require organisational learning in order to improve their capacity.

Lastly, today's learners are characterised much by their behaviour such as multitasking, competencies skills vis critical thinking, problem solving, preference for communication and collaboration offline and online (Jerald, 2013). Conversely, learners are utilising more and more of digital communication tools such as social media, mobile devices and others in their daily chores including learning. These innovative social media and technologies impacted the processes of production and distribution of goods and services dramatically in the digital village across the globe. They ushered in the era of economic integration across geopolitical and regional divides. And with the emergence of the services sector overtaking the manufacturing sector now become the centrepiece in the knowledge economy.

In turn, this will gravitate towards new approaches in teaching, training and learning. As for economic integration, it will involve standardisation of skills and competences globally for the performance of different economic functions visà-vis the education systems are no longer concentrating on the domestic market alone. They are called upon to prepare the globally competitive knowledge worker.

\section{Preparing future learners}

It could be argued that all educators participate in some form of reflective practice when thinking about planning and assessment. What is muddled is whether teachers have time to reflect deeply - to think consciously and purposefully about the learning they facilitate. With time a precious commodity, and new technology an ever-increasingly available tool, teachers literally have a wealth of intelligence at their finger tips that stretches far beyond the classroom walls. By highlighting the limitations of traditional theories around reflective practice, it is plausible to consider the benefits offered by new technologies. Social media allow educators access to perhaps the widest and most responsive support network that teaching has seen to date. So in examining how to prepare learners for tomorrow, both learners and educators' perspectives are discussed with a view that they are closely intertwined and influence each other.

\section{Students'perspective}

As 21 st century competencies involve cognitive, intrapersonal and interpersonal skills, this has implications for educators such as how to then impart these skills to learners? Of course, to develop higher order thinking skills, learners must first engage themselves in meaningful enquiries vis-à-vis learners must engage in active learning, working together collaboratively to construct knowledge. Another way that teachers can support student's learning is by exposing them to multiple different ways of approaching a situation (Diamond and Lee 2011). For this to work, the activity has to be sufficiently open-ended as there are multiple avenues to explore in pursuit of the answer. This exercises learner's flexibility and problem-solving, by getting them to think outside the box. This can be done in numerate subject like maths or accounting. Can teachers develop multiple approaches with learners, for example, by showing them a variety of ways to add up? Problem-solving and puzzling through different options will force the learners to actively think ahead and weigh up different solutions, rather than becoming proficient at reproducing the same set of actions repeatedly.

The common thread in various approaches is that it requires appropriate support. Left to their own (learners), choice and problem-solving could lead to chaotic classrooms where learners have no sense of bearing or limits. The role of the teacher, therefore, remains absolutely crucial. In some cases this means contingent scaffolding in the young learner's perspective (Sanders and Mazzucchelli 2013). Teachers will recognise that this is easier done in a small group or oneto-one than in large groups.

An on-going debate in educational and psychological research is the effectiveness of constructivist teaching methods over direct instruction. While constructivism can take many forms (such as discovery learning, inquiry learning, etc.), one commonality widely shared in the research community is that learning is constructed by the individuals, who are active sense-makers, rather than being just a reflection of external events (Mayer, 2004; Tobias, 2009). Nonetheless, proponents of direct instruction (e.g. Kirschner et al., 2006) have provided evidence that it is more efficient than discovery learning (minimal guidance during instruction) in teaching scientific concepts and processes. This view is also echoed by Alfieri et al. (2011), that unaided discovery generally does not generate beneficial learning outcomes, and accentuate the need for teachers to support learners with scaffolded tasks, feedback and worked examples. In the case of young learners in particular, most of the researchers on both sides of the divide agree that direct instruction is paramount when dealing with new content (e.g. Paas and van Gog, 2006; Tobias, 2009). 
In contrast, constructivism is pertinent in today's information technology environment with millennium learners having their own mobile devices to access information and learns at their own pace. Furthermore, with social media, learners also interact with other learners in cyberspace overcoming geographic barriers.

Connectivism is a pedagogy for digital learning and posits that learning takes place across a series of online networks (Downes, 2012). More specifically, knowledge is not the outcome of social engagement but is the connections formed by networks of distributed knowledge within online environments. MOOCs (massive open online courses) are examples of connectivism in practice, in which learning takes place exclusively online. In this method of learning, there is no requirement to engage with resources, students or tutors within traditional physical learning spaces. It is therefore often virtual, asynchronous and non-proximal. Flexibility and autonomy are fundamental to connectivism, and digital learning provides the perfect environment in which to support learners in making their own choices.

Indeed contemporary learners including millennials delight in experiential learning or learning by doing (Kolb, 1984; Teo \& Low 2018, Phillips \& Trainor, 2014; Roehl, Reddy \& Shannon, 2013). Experiential learning allows learners to engage in the learning process through active participation and activities involving critical thinking. Learners also engage with their peers, receive feedback from teacher and reflect on their experiences. In similar vein, teachers think of integrating active learning strategies into lesson delivery, setting clear expectations, designing effective evaluation strategies and provide helpful feedback. By having a great learning experience, there is a positive relationship between the learner and the teacher or other caring adult.

\section{Purposeful learning}

Today's learners are characterised by behavior such as multi-tasking, preference for variety of choices, open to challenges, possess short attention span and love exploiting digital tools to communicate (IEAB, and Jerald, 2013). How then can we ensure that learners stay focused on purposeful tasks when they are put through their overall challenge in class? According to Wallace et al (2012) learners are able to undertake a self-explanatory, collaborative, idea-sharing and developmental approach to their learning. By using TASC (Thinking Actively in a Social Context) approach, learners are guided through their challenge process. Although this helps drive the overall approach to learning, teacher's role here is more traditional vis-à-vis to plan the key knowledge and understanding that students need to learn, ensuring that there is clear subject based learning. Elder (2012) concurs that when we know the reason behind why we are doing something, we value it, and connect it to other aspects of our lives and engage with it on an individual level.

TASC is one of the tools for engaging learners in more challenging circumstances. Learners care more, try harder, and have more ownership in their learning. They talk about their learning with passion and purpose. They understand why they need to learn so that they can achieve their challenge, which they have co-created.

\section{Collaborative learning}

To develop interpersonal skills collaborative learning is the use of small group where learners work together to maximize their own learning (Johnson, Johnson \& Smith, 2007). The EEF (2018) argues that the impact of collaborative learning is consistently positive, although it is explicit in highlighting that this impact can be affected by group size and poor planning. They contend that the greatest learning gains are as a result of structured approaches and well-designed tasks and suggested that approaches which promote conversation and interaction between learners tend to yield positive results.

Collaborative learning provides learning in a safe environment where learners learn and cooperate in small group setting. Writers like Felder \& Brent (2007); Lea et al (2003) and Loh \& Teo (2016) concluded that collaborative learning promotes active learning in which earners learn through active engagement with one another instead of passively listening to instructor's teaching. As learners established stronger foundation and deeper understanding of subject content, knowledge is retained longer hence resulting in better academic results. Subsequently, learners' confidence and self-esteem improve. From the social aspect, learners in the process of working in groups or collaborative activities would also develop their interpersonal, oral communication and social skills (Van den Bossche et al, 2006).

Critics of collaborative learning often point to problems that are structural, such as inexplicit learning objectives and little accountability. For example, group work may place too much burden on some students, and in mixed ability groups can lead to the more able doing most of the work. There is also a danger that group work encourages lowerlevel thinking and ignores the strategies necessary for critical or higher-level thought. However, these shortcomings are often a result of poor planning and execution, rather than the approach itself. 
Going forward, educators will need to ensure that teachers and managers are comfortable in adapting strategies that have produced good outcomes for a majority of learners. Educators need to understand that they (learners) must feel safe in taking risks and that they have the support of teachers to do so.

\section{Immersive learning}

Immersive learning refers to identifying learner's interests and ascribing the 'zones of relevance' in their imagination vis-à-vis finding the cusp between what teachers need to teach and what students want to learn about. One example is a field trip or excursion for students to gain first-hand knowledge, experience and understanding of content. To the students, it is an experiential learning but to educators, it is helping students see an example in the real world of what teachers are driving their learning towards (Teo and Low 2018). By giving students a sense of the world beyond school, educators are seeking different things that spark their learners' interest and expand their realms of relevance. Immersion is vital, particularly for young learners who may have limited life experiences to draw upon. By immersing them in the world of their challenge, we are giving them experiences to stimulate learning.

Moreover, this connects to the real and purposeful aspects of the curriculum by stimulating planning and decisionmaking by learners and educators. What will they need to learn, know, and be able to do in order to achieve their learning challenge?

\section{Learning approaches}

Traditionally, the introduction of rote learning starts when learners enter primary school. This encompasses memorisation, drilling and examinations. This academic rigour is design to build students up to become highly disciplined young learners. Physical cues in a book (spatio-temporal aspects, such as touch and page-turning) better support readers in navigating texts in an intuitive way and that longhand note-taking on paper is more effective than on a laptop. Arguably, there have been benefits to this learning routine; however, the main drawback is that there is no deep learning; there is no opportunity for freedom and time to explore topics in greater depths. This exploration is crucial to the development of critical thinking (Hare 1999, Paul 2007, Elder and Paul 2010).

The present way of assessing students (predominately through examinations) has served generation of learners well. It is good at assessing student's ability to retain, understand and analyse information. But, it does not help in cultivating skills like resourcefulness, teamwork, creativity, presentation skills etc. Currently, as students move from primary to secondary to tertiary education, creativity is increasingly treated as a desirable skill that one should possess.

Blended learning is viewed as alternate approach especially for the millennium learners and aptly described by Garrison and Kanuka (2004) as the thoughtful integration of classroom face-to-face learning experiences with online learning experiences. This approach is mainly useful in building learning communities, and there is a reasonable body of supporting evidence for the benefits of digital learning technologies (Higgins et al 2012). Nevertheless, it is important not to over-rely on digital technology.

There are many forms of technology (i.e. wikis, blogs, education games, apps, etc.) exist and are available to learners at little or no cost. However, if educators were to use these forms of technology correctly or in conjunction with lesson planning, the bridge between education and technology would be lessened. The argument is that technological novelties must be adapted into instructional tools otherwise it will not be helpful. Conversely, teachers must conjointly become 21 st century educators.

Bloom's taxonomy originally was one-dimensional with an exclusive focus on the knowledge domain but educators use Bloom's Taxonomy and Bloom's Revised Taxonomy (two-dimensional) as a necessary and important hierarchical instructional set of cognitive processes designed to structure appropriate learning experiences with the hope of positive academic outcomes for their students (Anderson et al 2001, Krathwohl 2002, Growe 2011,).

Adding to the intricacy of learning approaches, extant literatures also show the importance of culture in influencing students' learning styles. In today's multiracial classroom dynamics, educators should be mindful of the role of mixed cultures weakening the effect of national cultures and hence may have an effect on learning styles (Loh and Teo 2016). Their research also revealed that learners' performance and outcome can be improved by leveraging multiculturalism rather than a hindrance force on learning and this form part of 21 stcentury learning.

\section{Teachers'perspectives}

Educators need to appreciate that there are four levels of philosophy regarding learning from behaviourism which assumes that learning as merely involving the memorisation and reproduction of content/facts materials. Students' outcome is being measured predominantly by exams/assessment-based results. In cognitivism, learners are engaged in the active information processing where learning is understanding and a mental state of activities. 
Cognitivism focuses on the inner mental activities - opening the "black box" of the human mind is valuable and necessary for understanding how people learn. Mental processes such as thinking, memory, knowing, and problemsolving need to be explored. Knowledge can be seen as schema or symbolic mental constructions. Learning is defined as change in a learner's schemata (Ertmer and Newby 1993, Cooper 1993).

The role of memory and superficial recall of facts play a pivotal role in determining its outcome. In social constructivism, learning is being viewed as construction of knowledge where learning involves applying, interpretative aimed at understanding reality. Active learning is promoted and students taking responsibility in self-directed learning. Answers and problem-solving takes place with students working together. Humanism refers to learning as personal empowerment, self actualisation, self-esteem is being boosted with praise. Invariably students' confidence is heightened as a result. For effective teaching to take place, then educators' paradigm will need to move beyond behaviourism to cognitivism and eventually towards social construct.

\section{Teaching perspectives}

According to Pratt (2002), a perspective on teaching is pivotal for effective teaching and learning strategies; and is an inter-related set of beliefs and intentions that gives direction and justification of teachers' lesson delivery. It is seeing through an educator's lens of how they view teaching and learning. To this end, all may espouse the use of higher-level questions as a means of promoting critical thinking. Pratt et al (2001) puts forward four central tenets of teaching which includes transmission, apprenticeship, developmental, nurturing and social reform. In more convenient terms, it means a set of key beliefs, primary responsibilities, typical strategies, and common difficulties. Hence if teachers are to improve in their teaching repertoire, they must reflect on what they do, why they do it, and on what grounds those actions and intentions are justified. It is obvious that there is no such thing as 'one size fits all' approach to development and evaluation, how can these perspectives help in that process?

As learners become more competent, the teacher's role changes vis teachers offer less direction but give added responsibilities to learners. Consequently, it is the transit from 'show and tell', scaffolding the teaching/instruction according to learners' stage of development. The key consideration for teachers is therefore finding the right balance between stages of development and scaffolding of teaching delivery takes time and patience. It is what faculty development should be, rather than the mastery of technique (Pratt and Collins 2001)

\section{Instructional pedagogies}

Knowledge-rich curricula are centred on the belief that some knowledge is more powerful than others; hence this knowledge should be the integral part of curriculum which all learners have a prerogative to it (Moore 2013). In turn, this prerogative places subject knowledge to the forefront of teaching and learning pedagogies and demand teachers to have expertise across subject domains. Berliner (2004) proposes that experts codify knowledge so as to be able to draw on it again, and it is through this codification that teachers grow their pedagogical content knowledge and develop expertise across the multiple domains that teachers are expected to know.

It leads us to ask 'so where we are going?' Young notes that real educational change will always be slow because the learning involved in acquiring real knowledge takes time and can challenge the deepest identity of learners (Young et al 2014). Yes, although we made a significant amount of progress toward realising our aims of delivering 21 st century competencies skills to students, there is still much work to be done - not the least of which is sustained professional development for all educators/leaders, expressly related to subject knowledge that will support nuanced and responsive teaching of the school's strategic plan.

\section{Capitalising on technologies}

The Partnership for 21st century skills (2008) has spelt out the use of digital technologies to transform schools and curriculum (PS21). Technologies has its place primarily to allow individuals to access information vis-s-vis to search, filter and manage information but has now expanded to create myriad of ways to communicate and share information such as social media, blogs or creative content. On the one hand, if users do not engage with the content sufficiently well, it will evoke their curiosity to think deeper and even raises questions. There is a need to have learners shift away from content and instead equip learners with the competencies to critique and evaluate knowledge (Tan et al, 2017a). To this end, learners must be engaged in interpreting, analyse information and subsequently make sound and timely decisions.

We have witnessed a significant growth in the amount of digital technologies available to use within educational environments, although there is debate around whether they are being used effectively (Casey et al 2017, Fullan 2013). Whilst exploiting on the significance of digital technologies and their ability to engage learners, it is imperative to consider both the strengths and potential pitfalls of using these tools within the education environment. 
For example, there is an increasing body of knowledge surrounding the role social interaction plays in physical education (Acquaviva et al 2013). Literature has highlighted the importance of social interaction within primary PE in particular (Cremin and Burnett 2018) and the negative impact that an ever-growing focus on digital technology may have on students' development (Casey 2011). It is, therefore, important that digital technology does not take away from the social element of learning; instead, it should be used to enhance interactions to develop learning further.

\section{Collaboration with other stakeholders}

Implementing 21st century competencies amongst students require not only the partnership of students but an entire ecosystem of stakeholders including educational institutions, society, and parents changing the value system of how we evaluate and look at education. As suggested by Tan (2017) and Teo \& Low 2016), both government and nongovernmental organisations (NGOs) need to take a concerted effort to prepare students for the tomorrow.

Volunteers can complement teachers by training students in their work-readiness, real world experience through a variety of programmes. Students need to be proactive in their participation of community work instead of being used to achieve their overall grade points computation (Liew, 2016). The Asia Society (2016) provided a summary how a sample of several countries that are taking the initiatives to develop framework to build 21st century competencies.

Table 2: How Education Systems Are Addressing 21st Century Skills

\begin{tabular}{|c|c|c|c|c|c|}
\hline $\begin{array}{l}\text { Hong } \\
\text { Kong }\end{array}$ & Japan & China & Finland & Singapore & $\begin{array}{l}\text { United } \\
\text { States }\end{array}$ \\
\hline $\begin{array}{l}\text { Learning to } \\
\text { Learn reform } \\
\text { addresses } \\
\text { applied } \\
\text { learning and } \\
\text { "other" } \\
\text { learning } \\
\text { experiences, } \\
\text { including } \\
\text { service and } \\
\text { workplace } \\
\text { learning } 6\end{array}$ & $\begin{array}{l}\text { Zest for Living } \\
\text { education reform } \\
\text { stresses the } \\
\text { importance of } \\
\text { experimentation, } \\
\text { problem finding, } \\
\text { and problem } \\
\text { solving instead of } \\
\text { rote } \\
\text { memorization }\end{array}$ & $\begin{array}{l}\text { Greater } \\
\text { emphasis on } \\
\text { students' } \\
\text { ability to } \\
\text { communicate } \\
\text { and work in } \\
\text { teams, pose } \\
\text { and solve } \\
\text { problems, and } \\
\text { learn to learn }\end{array}$ & $\begin{array}{l}\text { New focus on } \\
\text { "citizen skills": } \\
\text { (1) thinking } \\
\text { skills, including } \\
\text { problem } \\
\text { solving and } \\
\text { creative } \\
\text { thinking; } \\
\text { (2) ways of } \\
\text { working and } \\
\text { interacting; } \\
\text { (3) crafts and } \\
\text { expressive } \\
\text { skills; } \\
\text { (4) participatio } \\
\text { n and initiative; } \\
\text { and (5) self- } \\
\text { awareness and } \\
\text { personal } \\
\text { responsibility } 9\end{array}$ & $\begin{array}{l}\text { New } \\
\text { Framework } \\
\text { for } 21 \text { st } \\
\text { Century } \\
\text { Competencies } \\
\text { and Student } \\
\text { Outcomes is } \\
\text { intended to } \\
\text { better position } \\
\text { students to } \\
\text { take advantage } \\
\text { of global } \\
\text { opportunities }\end{array}$ & $\begin{array}{l}\text { Common Core } \\
\text { State } \\
\text { Standards } \\
\text { Initiative } \\
\text { redefines } \\
\text { standards to } \\
\text { make them } \\
\text { "inclusive of } \\
\text { rigorous } \\
\text { content and } \\
\text { applications of } \\
\text { knowledge } \\
\text { through } \\
\text { higher-order } \\
\text { skills, so that } \\
\text { all students are } \\
\text { prepared for } \\
\text { the } 21 \text { st } \\
\text { century"11 }\end{array}$ \\
\hline 2000 & 2006 & 2010 & 2010 & 2010 & 2010 \\
\hline
\end{tabular}

Source: Teaching and Learning 21 st Century Skills Lessons from the Learning Sciences, A Global cities education report, Asia Society, Partnership for Global Learning, 2012.

A case in point is the Singapore Ministry of Education (MOE) where the ministry not only play the pivotal role in regulating and managing education in Singapore but also spearheaded the shift towards to 21st century competencies with the introduction of "Thinking Schools, Learning Nation (TSLN) in 1997 to prepare students for the future with the rapid pace of globalisation (Tan et al 2017b) with the launch of 21CC.

By coaching students to be creative and empowering critical thinking skills; with greater emphasis on processes instead of outcome-based in teaching and learning, learners take charge, being more responsible and accountable in their learning and civic mindedness (MOE, 2006 and Tan, et al., 2017). Indeed, the 21CC framework has been integrated into students' learning, co-curriculum activities and teaching of character; citizenship education in secondary schools (age 13 - 16 years). MOE's 21CC framework formalised in 2010 as shown in Figure 3 with the three different levels of students' outcome. 


\section{Figure 3: Ministry of Education, Singapore framework}

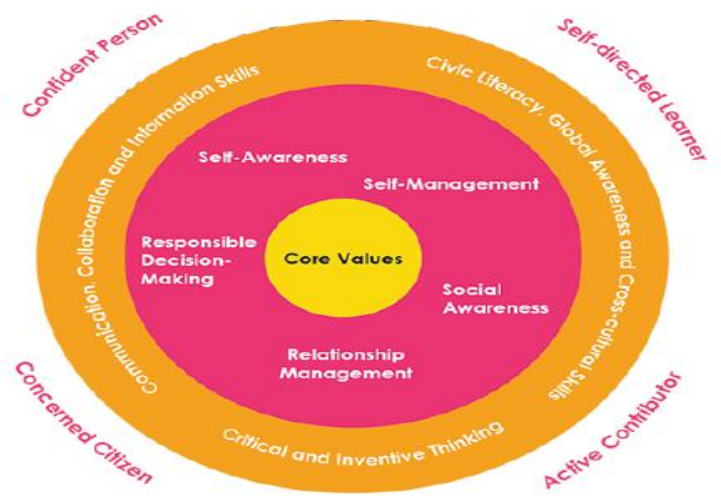

Source: Framework for 21CC and desired student outcomes. https://www.moe.gov.sg/education/education-system/21stcentury-competencies. MOE, Singapore.

\section{Conclusion}

To conclude, the approach to pedagogy, educational leadership and in-house professional development e.g. life-long learning, etc. has been germinating, over the last 25 years or so, in a variety of different research and development groups around the world. Several are spin-offs from Harvard University's long-running Project Zero, including Studio Thinking (Hetland et al 2007), Cultures of Thinking (Ritchhart 2015), There is the Cambridge University-led project on Learning without Limits (Hart et al 2004), and the various countries' Ministry of Education (MOE, 2016)advancing 21 st century competencies around Asia e.g. Singapore, South Korea, Japan Hong Kong, Taiwan. The common thread and unifying theme is what Claxton G (2018) describe as the learning power approach where we teach learners to teach themselves.

The learning power approach propounded by Claxton (2018) addresses several learning and teaching approaches and potential conflicts of instructional techniques that currently exist between supporters of traditional and progressive approaches to teaching. The hard and soft slants in delivering effective learning and teaching must be woven seamlessly together. Bringing it altogether, we now have a lucid approach to pedagogy, which is:

(a) established on a clear vision of the desirable outcomes of a 21st-century education (which includes knowledge, literacies and attitudes)

(b) derived from contemporary research in the cognitive sciences

(c) translated into a all-purpose learning design principles for humanising the desired outcomes

(d) unpacked into bite-sizes, practical tweaks to practice that can be contextualised

(e) reinforced by the direction and process of culture change at a institutional level, and a real-world model of school leadership

(f) link to an acceptable set of assessment practices

In retrospect, notwithstanding elementary (primary) level, learners should be building collaboration skills, nurturing their curiosity and learning to reflect on their learning and the progress they have made (Teo 2019). To that end, the audacity to move away from rigid examinations/assessments rudiments is a conscious awakening in promulgating holistic learning, where more time can be channeled towards quality pedagogies focused on inculcating 21 st century competencies (Teo 2019). Invariably this translates to placing an emphasis on not just the hard skills, but rather on the soft skills such as teamwork, problem-solving and emotional quotient. These skills are transferable and increasingly more relevant and lend credence to real-work employment.

Finally, as Montrieux et al (2015) points out that if teachers/managers truly seek to become a change agent in educational system, then they need to rethink the teaching and learning approaches through multiple perspectives and reconstruct a richer and more balanced view about the essence of education. Only if the teaching and learning yield meaningful connections, drive impetus in teacher learning and transcend traditional disciplinary boundaries of the school curriculum, will provide direction in education.

\section{References}

21st Century Competencies: Learning to Learn, SingTech, issue 45, Nov/ Dec 2013, www.singtech.nie.edu.sg 
21 st century competencies, Towards Defining 21st century Competencies for Ontario, Foundation document for Discussion, 2016 Edition.

Acedo, C., \& Hughes, C. (2014). Principles for learning and competences in the 21st-century curriculum. Prospects, 44(4), 503-525.

Alfieri L, Brooks PJ, Aldrich NJ et al. (2011). Does discovery-based instruction enhance learning? Journal of Educational Psychology 103: 1-18.

Anderson, L. W., Krathwohl, D. R., \& Bloom, B. S. (2001). A taxonomy for learning, teaching, and assessing: A revision of Bloom's taxonomy of educational objectives. New York: Longman.

Acquaviva J, Beaudet R and Maina M (2013). Technology in physical education: Striking a delicate balance. The Global Journal of Health and Physical Education Pedagogy 2(3): 197-204.

Asia Society (2012), Teaching and Learning 21st Century Skills Lessons from the Learning Sciences, A Global cities education report, , Partnership for Global Learning.

Berliner D (2004). Describing the behavior and documenting the accomplishments of expert teachers. Bulletin of Science, Technology, \& Society 24(3): 200-212.

Brame CJ and Biel R (2015) Setting up and facilitating group work: Using cooperative learning groups effectively. Available at: http://cft.vanderbilt.edu/guides-sub-pages/setting-up-and-facilitating-group-workusing-cooperative-learninggroupseffectively/ (accessed 2 April 2019)

Casey A (2011) Using digital technology to enhance student engagement in physical education. Asia-Pacific Journal of Health, Sport \& Physical Education 2(2): 51-65.

Casey A, Goodyear V and Armour K (2017). Rethinking the relationship between pedagogy, technology and learning in health and physical education. Sport, Education and Society 22(2): 288-304.

Carnevale, A. (2013). 21st Century Competencies For College and Career Readiness, Skills for career success in the 21st century, www.ncda.org

Chesbrough, H., (2013). Open business models: How to thrive in the new innovation landscape. Harvard Business Press.

Cedefop (2016). Work programme (2016), European Centre for the Development of Vocational Training.

Celik N (2014) The transition from classical organizations to learning organization in accommodation businesses: The case of in the service sector. The Macrotheme Review 3: 88-98.

Claxton G (2018). The Learning Power Approach: Teaching Learners to Teach Themselves. Carmarthen: Crown House.

Cooper, P. A. (1993). Paradigm Shifts in Designed Instruction: From Behaviorism to Cognitivism to Constructivism. Educational technology, 33(5), 12-19.

Cremin T and Burnett C (eds) (2018). Learning to Teach in the Primary School. London: Routledge.

Davis, G. A. (2006). Gifted children and gifted education: A handbook for teachers and parents. Scottsdale, AZ: Great Potential Press.

Diamond A and Lee K (2011). Interventions shown to aid executive function development in children 4 to 12 years old. Science 333(6045): 959-964.

Downes S (2012). Connectivism and Connective Knowledge: Essays on Meaning and Learning Networks. Ontario: National Research Council Canada.

Education Endowment Foundation (2018) Teaching and learning toolkit - collaborative learning. Available at: https://educationendowmentfoundation.org.uk/evidence-summaries/teaching-learning-toolkit/collaborative-learning (accessed 2 April 2019).

Elder, L., and Paul, R. (2010) Critical Thinking Development: A Stage Theory - With Implications for Instruction, The Foundation for Critical Thinking.

Elder Z (2012). Full on Learning. Crown House Pub Limited.

Ertmer, P. A., \& Newby, T. J. (1993). Behaviorism, cognitivism, constructivism: Comparing critical features from an instructional design perspective, Performance improvement quarterly, 6(4), 50-72.

Felder., R. N., \& Brent, R., (2007), Cooperative learning, Raleigh, NC 27695-7905 2, Education Designs, Inc., Cary, NC 27518 , N.C. State University

Framework for 21st Century Learning - P21, http://www.p21.org, retrieved on March 2014.

Fullan M (2013). Stratosphere: Integrating Technology, Pedagogy, and Change Knowledge. Toronto: Pearson.

Garrison D and Kanuka H (2004). Blended learning: Uncovering its transformative potential in higher education. Internet and Higher Education 7(2): 95-105.

Growe, R. (2011), The new inquiry in education: Reshaping the skill demands of today's students, Schooling, 2(1), 1-7.

Hare, W. (1999). Bertrand Russell on Critical Thinking, Journal of Thought 36,1,2001:7-16, and was first published in the Proceedings of the Twentieth World Congress of Philosophy (The Paideia Project On-line), 1999.

Hart S, Dixon A, Drummond M, et al. (2004) Learning without Limits. Maidenhead: Open University Press

Hetland L, Winner E, Veenema S, et al. (2007) Studio Thinking: The Real Benefits of Visual Arts Education. New York: Teachers College Press.

Higgins S, Xiao Z and Katsipataki M (2012) The impact of digital technology on learning: A summary for the Education Endowment Foundation. Available at: 
https://educationendowmentfoundation.org.uk/public/files/Publications/The_Impact_of_Digital_Technologies_on_Learning (2012).pdf (accessed 3 April 2019).

International Education Advisory Board (IEAB), Learning in the 21st century, Teaching Today's Students on Their Terms, CERTIPORT, U.S.A.

Jerald, C.R, Defining a 21st Century Education: At a glance, Retrieved from

<www.centerforpubliceducation.org/Learn-About/21st Century>, viewed 5th August, 2013.

Johnson D.W., Johnson R., and Smith, K. (2014). Cooperative learning: Improving university instruction by basing practice on validated theory. Journal on Excellence in University Teaching 25(4): 1-26.

Johnson, D.W., Johnson,R., and Smith,K. (2007). The state of cooperative learning in postsecondary and professional settings. Educational Psychology Review, 19, 15-29.

Juggernaut, (2016). On Demand Economy: Statistics that Define the Future of On Demand Startups. Retrieved from http://nextjuggernaut.com/blog/on-demand-economy-survey-stats-future-economy-funding-trends-on-demandstartups/.

Kirschner PA, Sweller J and Clark RE (2006). Why minimal guidance during instruction does not work: An analysis of the failure of constructivist, discovery, problem-based, experiential, and inquiry-based teaching. Educational Psychologist 41: 75-86.

Kay, K. (2008). Partnership for 21 century skills, Retrieved February 2019 from http://www.p21.org/storage/documents/ken_kay_testiony_for_rnc_platform_committee.pdf

Koh, A. (2013). A vision of schooling for the twenty-first century: Thinking Schools and Learning Nation. In Z. Deng, S. Gopinathan, \& C. K-E. Lee (Eds.), Globalisation and the Singapore curriculum: From policy to classroom (pp. 4963). Singapore: Springer Science+Business Media.

Kolb, D. (1984), Experiential Learning: Experience as the source of Learning and Development, Englewood cliffs, NJ, Prentice Hall.

Krathwohl, D. R. (2002), A revision of Bloom's taxonomy: An overview. Theory into practice, 41(4), 212-218.

Lau, K. W., Ng, M. F., \& Lee, P. Y. (2009).Rethinking the creativity training in design education: A study of creative thinking tools for facilitating creativity development of design students.Art, Design \& Communication in Higher Education, $8(1), 71-84$.

Lea, S. J., D. Stephenson, and J. Troy (2003). Higher Education Students' Attitudes to Student Centred Learning: Beyond 'educational bulimia'. Studies in Higher Education. 28(3), 321-334.

Lee, S. S., \& Hung, D. (2016). A socio-cultural perspective to teacher adaptivity: The spreading of curricular innovations in Singapore schools. Learning: Research and Practice, 2(1), 1-21.

Loh, C.Y. and Teo, T.C. (2016). Students' Perception of Collaborative Learning, Conflict Management and Satisfaction in a Private Educational Institution Learning Environment: An Asian Case Study, Journal of Education \& Social Policy, 3(3).

Loh, C.Y. and Teo, T.C. (2017). Understanding Asian Students Learning Styles, Cultural Influence and Learning Strategies, Journal of Education \& Social Policy, 7(1).

Liew, S. G., (2016), Revamp traditional classroom to impart 21 $21^{\text {st }}$ century skills, Straits Times, April, 2016. http://www.straitstimes.com/forum/letters-in-print/revamp-traditional-classroom-to-impart-21st-century-skills

Mayer RE (2004). Should there be a three-strikes rule against pure discovery learning? American Psychologist 59: 14-19.

Montrieux H, Vanderlinde R, Schellens T, De Marez L (2015). Teaching and Learning with Mobile Technology: A Qualitative Explorative Study about the Introduction of Tablet Devices in Secondary Education, PLoS ONE 10(12).

Moore R (2013). Social realism and the problem of the problem of knowledge in the sociology of education. British Journal of Sociology of Education 34(3): 333-353.

Ministry of Education. (MOE), 2005. Greater support for teachers and school leaders. Retrieved from https://www.moe.gov.sg/media/press/2005/pr20050922b.htm.

Ministry of Education (MOE), 2016, 21st century competencies.

OECD (2013) Innovative Learning Environments. Educational Research and Innovation. Paris: OECD Publishing.

OECD (2016). Skills for a digital world. Retrieved January 15, 2016, from https://www.oecd.org/els/emp/Skills-for-aDigital-World.pdf

O'Neil J (1995) On schools as learning organisations: A conversation with Peter Senge. Educational Leadership 52(7): 2033.

Paas F and van Gog T (2006). Optimising worked example instruction: Different ways to increase germane cognitive load. Learning and Instruction 16: 87-91.

Partnership for 21st century skills (2008), 21st Century Skills, Education and Competencies, A Resource and Policy Guide, Tucson, USA

Patel, S., (2016). In defense of the Uber-ization of everything. Retrieved from https://techcrunch.com/2016/06/19/in-defenseof-the-uber-ization-of-everything/.

Paul, R. (2007), Critical Thinking in Every Domain of Knowledge and Belief, The 27th Annual International Conference on Critical Thinking, Keynote Address -- July 23, 2007. 
Phillips, C.R. and Trainor, J.E. (2014), Millennial students and the flipped classroom, Journal of Business and Educational Leadership, 5(1), 102-112.

Pratt, D. D. (2002).Good teaching: one size fits all? In An Up-date on Teaching Theory, Jovita Ross-Gordon (Ed.), San Francisco: Jossey-Bass, Publishers.

Pratt, D.D. and Collins, J.B. (2000). The Teaching Perspectives Inventory, Proceedings of the 41st Adult Education Research Conference, Vancouver, B.C.

Pratt, D.D., \& Collins, J.B. (2001). Summary of five teaching perspective. <http://www.teachingperspectives.com/drupal/tpi/summary-five-perspectives> viewed on 10 July 2015

Pratt, D.D, Collins J. B., Selinger, S, J., (2001). Development and Use of The Teaching perspectives Inventory (TPI), U.S.A.

Puccio, G. J., \& Keller-Mathers, S. (2007). Enhancing thinking and leadership skills through creative problem solving. In A. G. Tan (Ed.), Creativity: A handbook for teachers (pp. 281-301). Hackensack, NJ: World Scientific.

Ritchhart R (2015) Creating Cultures of Thinking. San Francisco: Jossey-Bass.

Roehl, A., Reddy, S. L. \& Shannon, G. J. (2013), The flipped classroom: An opportunity to engage millennial students through active learning strategies, Journal of Family and Consumer Sciences, 105(2), 44-48.

Sanders M and Mazzucchelli T (2013). The promotion of self-regulation through parenting interventions. Clinical Child and Family Psychology Review 16(1): 1-17.

Saracho, O. N. (2002). Young children's creativity and pretend play.Early Child Development \& Care, 172(5), 431-438.

Schleicher A (2015). Schools for 21st-Century Learners: Strong Leaders, Confident Teachers, Innovative Approaches. International Summit on the Teaching Profession. Paris: OECD Publishing

Tan, J. P-L., Choo, S.S., Kang, T. and Liem, Gregory. A. D. (2017a), Educating for twenty-first century competencies and future-ready learners: Research perspectives from Singapore, Asia Pacific Journal of Education.

Tan, J.P. Koh, E., Chan, M. Costes-Onishi, P. and Hung, D. (2017b), Advancing 21st Century Competencies in Singapore, Asia Siciety, Center for Global Education, Singapore.

Teo, J. E., Deng, Z., Lee, C. K-E., \& Lim-Ratnam, C. (2013). Teach less, learn more: Lost in translation. In Z. Deng, S. Gopinathan, \& C. K-E. Lee (Eds.), Globalisation and the Singapore curriculum: From policy to classroom (pp. 99 117). Singapore: Springer Science+Business Media.

Teo, T.C. (2019). Are We Done Yet? A Critical Analysis of Promoting Student Engagement in an Era of Accountability in Myanmar, International Journal of Humanities and Social Science, 9(2) February 2019.

Teo, T.C. and Low, K.C.P. (2016). Facilitating Adult Learning in Private Educational Institutions in Singapore: A Singaporean Perspective, Paper submitted and presented at E-Leaders Conference in Vienna, Technische Universität Wien (or TU Wien), Argentintinierstraße 8, June 4-6, 2016

Teo, T.C. and Low, K.C.P. (2018). Reconstructing the Global Education and Learning Strategies to Enhance 21st Century Learning Skills: Learning Experience on a Global Perspective across Curriculum, Journal of Education \& Social Policy, 5(2), June 2018.

Tobias S (2009). An eclectic appraisal of the success or failure of constructivist instruction. In: Tobias S and Duffy TM (eds) Constructivist Instruction: Success or Failure? London: Routledge, pp. 335-350.

Van den Bossche, P., W. H. Gijselaers, M. Segers, \& P. A. Kirschner (2006), Social and cognitive factors driving teamwork in collaborative learning environments: Team learning beliefs andbehaviors. Small Group Research 37(5): 490-521.

Vemić J (2007) Employee training and development and the learning organization. Journal of Economic Behavior and Organization 4: 209-216.

Wallace B, Bernardelli A, Molyneux C, et al. (2012). TASC: Thinking Actively in a Social Context. A universal problemsolving process. Wallace B and Eriksson G (eds) Gifted Education International 28(1). SAGE Publications: 58-83.

Weston D and Clay B (2018). Unleashing Great Teaching: The Secrets to the Most Effective Teacher Development (1st edition). London and New York: Routledge.

Wiliam D (2016) Leadership for Teacher Learning: Creating a Culture where all Teachers Improve so that all Students Succeed (1st edition.) Florida: Learning Sciences International.

Young M, Lambert D, Roberts C, et al. (2014). Knowledge, curriculum, and the future school. In: Young M (ed.) Knowledge and the Future School: Curriculum and Social Justice. London: Bloomsbury, pp. 9-40. 